Saudi Journal of Business and Management Studies Abbreviated Key Title: Saudi J Bus Manag Stud ISSN 2415-6663 (Print) |ISSN 2415-6671 (Online) Scholars Middle East Publishers, Dubai, United Arab Emirates Journal homepage: https://saudijournals.com/sjbms

Original Research Article

\title{
Analysis the Influence of Investment Knowledge and Investment Habits against the Investment Champion in the Pandemic COVID Period: Evidence from Indonesia
}

\author{
Musdalifah Azis ${ }^{*}$ \\ Lecturer Department of Management Faculty of Economics and Business, Mulawarman University, Samarinda, Indonesia
}

\begin{tabular}{ll}
\hline DOI: $10.36348 /$ sibms.2020.v05i08.002 & | Received: 10.08 .2020 | Accepted: 18.08 .2020 | Published: 20.08 .2020
\end{tabular}

*Corresponding author: Musdalifah Azis

\section{Abstract}

Knowledge of investment regarding the characteristics of benefits and costs of mutual fund products is still very minimal and access to market information on the mutual fund is limited which can be an investment alternative that can be used by the Samarinda community. This Community Service Program aims to provide investment knowledge of mutual fund products through online media whose information can be accessed by every community, especially Samarinda. The PkM program was implemented in 5 sub-districts of welcome sub-districts and 5 sub-districts of Sungai Pinang sub-district on July 8 to August 182020 using the online / virtual face-to-face meeting method with online problem solving steps, namely the first step to provide investment knowledge education and introduction to mutual fund product characters, the second step is distributing online questionnaires to community respondents, the third step is processing the questionnaire data, and the fourth step is collecting empirical references and interpreting the observed data. The pandemic covid 19 , this motion as investors turned the people of refracting life changed, his extensive and complex investment and the confidence to reach the fixed investment can be achieved.This research includes 268 respondents, the data processed with validity test, reliability test and hypotheses test with analysis 1-10 scale semantic, the independent variable obtained that investment 56,2 percent knowledge and confidence can explain the variable dependent of champion investment in the pandemic covid19 Samarinda Town Kalimantan east of Indonesian society.

Keywords: Investment Knowledge, Investment Habits, The Investment Champion, mutual fund.

Copyright @ 2020: This is an open-access article distributed under the terms of the Creative Commons Attribution license which permits unrestricted use, distribution, and reproduction in any medium for non-commercial use (NonCommercial, or CC-BY-NC) provided the original author and source are credited.

\section{INTRODUCTION}

This study is to find out and understand the investment knowledge, investment habits and investment champions in the other nations in the behavior of investing in the pandemic Covid 19. The COVID 19 pandemic conditions [1-3], lead to changes in the behavior of a person or community conducting physical distancing by kee ping a distance and all activities carried out from home. The target to be achieved forms a hypothetical modeling of community investment behavior during the COVID -19 pandemic. Quantitative Method that will be used in analyzing the knowledge, beliefs and habits of investment champions conducted by the public during the pandemic covid-19 period, primary data obtained from community answers in an online questionnaire.

Community answers in the online questionnaire refer to the semantic scale 1-10 and use semantic analysis [4-8], after going through the stages of data validity and reliability, initial testing is carried out on a number of certain respondents using OLS multiple regression. This test is to determine the accuracy of the observation instrument in explaining the understanding of knowledge, beliefs and habits of the community investment champion in investment behavior during the COVID 19 pandemic. 
This research enlightens empirical studies to the public that when life changes, an investor must be able to immediately be more flexible and efficient in investing in his life. Investment knowledge [9-16] concerning the market is not controlled by anyone and anything [17] must be known by an investor, because of dynamic and liquid market movements [18], investment needs confidence so that it can enter into markets that are controlled by elastic market supply and demand factors [19], investors need to know the investment they have [20], some investments have minimum purchases1, because there are many things that investors do not need to know [21], avoid investing in emergency funds owned, because it can cause multiplied costs such as interest, and investors must be able to and make changes when life changes [22].

Investment behavior in an investor's life that has changed brings a public investment belief [23-25, $10,22,23,26]$, a belief or belief prediction of future market movements to get big returns, "Teacher": if I can't predict the market, other people can do it - what I need to do is find that person, believe that "inside information" is a way to make huge amounts of money, do diversification [27-29], and [30], believe that you have to take big risks to make big profits [8], belief in the "system" [12]: someone or somewhere, has built a system - an improvement in technical analysis, fundamental analysis, computerized trade, the Gann triangle, or even astrology - which will guarantee investment returns.

Investment knowledge is broad and complex and the existence of an investment belief is able to explain the habits of investment champions [17, 2, 31, 32 , 9] in society can be realized in various life conditions that change full of uncertainty, investment champion habits are investment winners over a concept of capital protection [33] will always be the first priority, risk averse loyalty [34, 8, 35, 36], building their own unique investment philosophy [37, 9, 1], Establish your own personal investment system [38] to choose, buy, and sell investments, Diversification [2830], investment is for birds (uncertainty), Investment Focus [11, 39] on returns after tax, and only investments that you understand, Refuse to make investments that do not meet your criteria, do your own research, Have patience without limits, Maintain extraordinary investments so that there are established reasons for me sell it, follow your system solemnly, admit your mistakes and correct them immediately, change mistakes into learning, you should try, not talk about what you do, know how to delegate, live far below your capacity, this is not about money, love what You don't do what you have, live and breathe by investing 24 hours a day and place your net value on investment funds.

\section{LITERATURE REVIEW}

In the current pandemic covid 19, investment knowledge about the market that could not be controlled by anyone and anything had a significant impact on the returns expected by investors, but the lowest information on all scales before and during the pandemic. Thus, it seems that the pandemic has not affected investors' expectations, because of the opportunities for diversification to invest in portfolios [40]. Successful investors do not rely on predictions for future market movements $[19,30]$. Media "gurus" make money from talking about investments, selling advice, or setting tariffs to manage other people's investments $[41,9,32]$. But a person or investor who finds a way to increase the value of his investment portfolio will not give that secret to others [42]. They Diversification is the opposite: having a small ownership in many companies' results in that although there is a spectacular return on an investment in a portfolio, the impact is small on the total value of your investment portfolio. A successful investor avoids risk is fundamental to accumulating wealth, they know that it is easier to lose money than to make it, therefore they pay more attention to steps to avoid losses rather than chasing profits.

An expert investor believes that his first priority is always to protect capital, which is the basis of his investment strategy; the result of such habits is antirisk. Building on his own investment philosophy, which is an expression of his personality, abilities, knowledge, tastes and objectives, as a result, no two investors are very successful, who share the same investment philosophy [37]. Forming, testing his own personal system [43] to choose, buy and sell investments. It is not true that investment diversification is the key to gaining great wealth, the portfolio of expert investors is concentrated, and it focuses its energy much more intensely and is far more effective in recognizing the right investment [42].

Companies that do not provide dividends, money will be taxed once, the company can collect retained income on the returns on equity. Expert investors hate paying taxes [44] (and other transaction costs), and manage their affairs to legally minimize tax accounts. Expert investors will only invest in what is understood by finding a market niche, gaining that understanding is difficult and time-consuming, and building an investment philosophy [37, 9], [1] determining the type of investment understood, and setting parameters of the circle of competency advantages which has positive average favorability.

An important investment for those who know how realistic they are to set what they don't know. The circle of competence provides investment interest, understanding knowledge [9, 13], 4] and willingness to understand investment. Expert investors continue to look for new investment opportunities that meet their 
criteria and are actively involved in their own research. When unable to find investments that don't meet its criteria, expert investors have the patience to wait until they find them and act immediately after making an investment decision.

Hold on to extraordinary investments so there are predetermined reasons to sell them [45, 9, 22, 39] because every successful investor has a selling strategy that suits their system, they will sell investments when they need capital to funding better investment opportunities [16, 1], [14, 8].

\section{RESEARCH METHOD}

In this study the population is the entire community of Samarinda, so the number of samples of this study were 268 respondents who live in each village in Samarinda, East Kalimantan, Indonesia. Data analysis tools used include validity test, reliability test and hypothesis test. The variables studied, among others: investment knowledge, investment confidence, and the habits of investment champions, there are 8 indicators of investment knowledge, 6 indicators of investment confidence and 21 indicators of investor champion habits which were carried out in this study.

Table-1: Validity Test of

\begin{tabular}{|c|c|c|c|c|c|c|c|}
\hline Item & $\begin{array}{c}\text { Pearson } \\
\text { Correlation }(r- \\
\text { count })\end{array}$ & r-table & results & Item & $\begin{array}{c}\text { Pearson } \\
\text { Correlation (r- } \\
\text { count) }\end{array}$ & r-table & Results \\
\hline X11 & $.391^{* * *}$ & 0.1199 & valid & X35 & $.684^{* *}$ & 0.1199 & Valid \\
\hline $\mathrm{X} 12$ & $.613^{* * *}$ & 0.1199 & valid & X36 & $.703^{* * *}$ & 0.1199 & Valid \\
\hline X13 & $.393^{* * *}$ & 0.1199 & valid & X37 & $.702^{* * *}$ & 0.1199 & Valid \\
\hline $\mathrm{X} 14$ & $.554^{* *}$ & 0.1199 & valid & X38 & $.557^{* *}$ & 0.1199 & Valid \\
\hline $\mathrm{X} 15$ & $.201^{* * *}$ & 0.1199 & valid & X39 & $.689^{* * *}$ & 0.1199 & Valid \\
\hline X16 & $.288^{* * *}$ & 0.1199 & valid & X310 & $.661^{* * *}$ & 0.1199 & Valid \\
\hline X17 & $.256^{* *}$ & 0.1199 & valid & X311 & $.808^{* *}$ & 0.1199 & Valid \\
\hline $\mathrm{X} 18$ & $.392^{* *}$ & 0.1199 & valid & X312 & $.786^{* *}$ & 0.1199 & Valid \\
\hline $\mathrm{X} 21$ & $.592^{* * *}$ & 0.1199 & valid & X313 & $.761^{* * *}$ & 0.1199 & Valid \\
\hline X22 & $.296^{* * *}$ & 0.1199 & valid & X314 & $.685^{* * *}$ & 0.1199 & Valid \\
\hline $\mathrm{X} 23$ & $.333^{* * *}$ & 0.1199 & valid & X315 & $.652^{* * *}$ & 0.1199 & Valid \\
\hline $\mathrm{X} 24$ & $.614^{* *}$ & 0.1199 & valid & X316 & $.768^{* *}$ & 0.1199 & Valid \\
\hline $\mathrm{X} 25$ & $.609^{* *}$ & 0.1199 & valid & X317 & $.445^{* *}$ & 0.1199 & Valid \\
\hline X26 & $.581^{* * *}$ & 0.1199 & valid & X318 & $.422^{* * *}$ & 0.1199 & Valid \\
\hline X31 & $.715^{* * *}$ & 0.1199 & valid & X319 & $.561^{* * *}$ & 0.1199 & Valid \\
\hline X32 & $.487^{* * *}$ & 0.1199 & valid & X320 & $.535^{* *}$ & 0.1199 & Valid \\
\hline X33 & $.704^{* * *}$ & 0.1199 & valid & X321 & $.584^{* * *}$ & 0.1199 & Valid \\
\hline X34 & $.749^{* * *}$ & 0.1199 & valid & & & & \\
\hline
\end{tabular}

Based on the above table, Items asked to respondents have r-count greater than r-table, so it can be said that the items are valid. And Cronbach's alpha with $\mathrm{N}$ of 35 items of 0.933 is greater than 0.65 , it can also be said that the item is reliable.

Table-2: Reliability Statistics

\begin{tabular}{|c|r|}
\hline Cronbach's Alpha & N of Items \\
\hline .933 & 35 \\
\hline
\end{tabular}

Source: Output SPSS

Because the questionnaire items of this study meet the validity and reliability tests, the questionnaires that have been made are appropriate and reliable in this study.

\section{RESULTS AND DISCUSSION}

Based on 268 respondents in this study using the semantic scale 1-10 with his analysis that 23.1 percent of the market is not controlled by anyone and anything, 21.3 percent of investment requires confidence, 32.1 percent knows your investment, 23.5 percent of some investment has minimum purchase, 21.3 percent many things you don't know about, 36.6 don't invest the emergency fund you have, 20.9 percent of the cost can double like interest and 46.3 percent you can and must make changes when life changes.

Community investment confidence is indicated by the 24.6 percent confidence in predicting future market movements to get large returns, 18.3 percent confidence in "Teacher": if I can't predict the market, other people can do it - what I need to do is find that person, 20.5 percent Believe that "inside information" is a way to make huge amounts of money, 25.4 percent 
Diversify, 18.7 percent believe you have to take big risks to make big profits, 21.3 percent confidence in the "system": someone or somewhere, has built a system an improvement in technical analysis, fundamental analysis, computerized trade, Gann triangle, or even astrology - that will guarantee investment returns.

The investment champion habit is indicated from 20.5 percent of capital protection being the first priority, 20.5 percent of risk-averse loyalty, 20.5 percent building up their own unique investment philosophy, 24.3 percent form a personal investment system, 26.1 percent investment diversification, 22, 4 percent of investments focus on after-tax returns, and
24.6 percent of investments are understood, 23.5 percent refuse to make investments that do not meet your criteria, 22 percent own research, 22.4 percent have unlimited patience, 20.9 percent maintain investment, 25.7 percent follow your system solemnly, 23.5 percent admit your mistakes and correct them immediately, change mistakes into learning, 29.5 percent you have to try, 19 percent don't talk about what you do, 19.4 percent know how to delegate, 25 percent live far below your capacity, 19 percent is not about money, 29.5 percent love what you do not what you have, 16.9 percent live and breathe invest 24 hours a day and 26.5 percent place your net value on investment funds.

Table-3: Descriptive Statistic

\begin{tabular}{|l|l|l|l|l|l|}
\hline \multicolumn{2}{|c|}{} & P_INVEST & K_INVEST & J_INVEST & Valid N (listwise) \\
\hline $\mathrm{N}$ & Statistic & 268 & 268 & 268 & 268 \\
\hline Minimum & Statistic & 5 & 3 & 3 & \\
\hline Maximum & Statistic & 10 & 10 & 10 & \\
\hline Mean & Statistic & 7.34 & 6.72 & 7.13 & \\
\hline Std. Deviation & Statistic & 1.039 & 1.261 & 1.263 & \\
\hline Variance & Statistic & 1.079 & 1.589 & 1.595 & \\
\hline \multirow{2}{*}{ Skewness } & Statistic & -.100 & .144 & -.048 & \\
\cline { 2 - 7 } & Std. Error & .149 & .149 & .149 & \\
\hline \multirow{2}{*}{ Kurtosis } & Statistic & -.657 & -.203 & -.306 & \\
\cline { 2 - 7 } & Std. Error & .297 & .297 & .297 & \\
\hline
\end{tabular}

\section{Source: Output SPSS}

Descriptive variables in this study include (1) the mean value of investment knowledge, investment habits and champions of investment, respectively 7.34, 6.72 and 7.13. (2). The Std Deviation of Investment Knowledge, Investment Habits and Investment Champions are 1,039, 1,261 and 1,263, respectively. (3). Variance of Investment Knowledge, Investment
Habits and Investment Champions are 1,079, 1,589, and 1,595, respectively. (4). Skewness of Investment Knowledge, Investment Habits and Investment Champion are $-0,100,0,144$ and $-0,048$, respectively. (5). Kurtosis of Investment Knowledge, Investment Habits and Investment Champions are -0,657, -0,203 and $-0,306$, respectively.

Table-4: One-Sample Kolmogorov-Smirnov Test

\begin{tabular}{|c|c|c|c|c|c|}
\hline & & P_INVEST & K_INVEST & J_INVEST & $\begin{array}{l}\text { Unstandardized } \\
\text { Residual }\end{array}$ \\
\hline \multicolumn{2}{|l|}{$\mathrm{N}$} & 268 & 268 & 268 & 268 \\
\hline \multirow{2}{*}{$\begin{array}{l}\text { Normal } \\
\text { Parameters }\end{array}$} & Mean & 7.34 & 6.72 & 7.13 & .0000000 \\
\hline & Std. Deviation & 1.039 & 1.261 & 1.263 & .83548107 \\
\hline \multirow{3}{*}{$\begin{array}{l}\text { Most Extreme } \\
\text { Differences }\end{array}$} & Absolute & .053 & .080 & .046 & .040 \\
\hline & Positive & .049 & .080 & .032 & .040 \\
\hline & Negative & -.053 & -.052 & -.046 & -.040 \\
\hline \multicolumn{2}{|l|}{ Test Statistic } & .053 & .080 & .046 & .040 \\
\hline \multicolumn{2}{|c|}{ Asymp. Sig. (2-tailed) } & $.070^{\mathrm{c}}$ & $.000^{\mathrm{c}}$ & $.200^{\mathrm{c}, \mathrm{d}}$ & $.200^{\mathrm{c}, \mathrm{d}}$ \\
\hline \multicolumn{6}{|c|}{ a. Test distribution is Normal. } \\
\hline \multicolumn{6}{|c|}{ b. Calculated from data. } \\
\hline \multicolumn{6}{|c|}{ c. Lilliefors Significance Correction. } \\
\hline \multicolumn{6}{|c|}{ d. This is a lower bound of the true significance. } \\
\hline
\end{tabular}

\section{Source: Output SPSS}

In the Kolmogorov-Smirnov One-Sample Table Test the Absolute value of 0.040 unstandardized residuals with the Kolmogorov-Smirnov table in sample $\mathrm{N}=268$ is 0.083 , then $0.040<0.083$, which means the data are normally distributed. This is evidenced by the results of the Kolmogorov-Smirnov test Statisctics test that look at the Asymp value. Sig. (2 tailed) the value is $0.200>0.05$ which means the data is normally distributed. 
In the ANOVA table, the Summary and Coefficients Model shows that the F Test of this model is significant $0,000<0.05$ with an $F$ value of 170.333 meaning that there is an influence of all independent variables namely investment knowledge and investment habits together towards investment champions in the pandemic COVID 19 period of the community samarinda.

Table-5: ANOVA a, Model Summary, and Coefficients

\begin{tabular}{|c|c|c|c|c|c|c|}
\hline \multicolumn{2}{|c|}{ Model } & Sum of Squares & df & Mean Square & $\mathbf{F}$ & Sig. \\
\hline \multirow[t]{3}{*}{1} & Regression & 239.594 & 2 & 119.797 & 170.337 & $.000^{\mathrm{b}}$ \\
\hline & Residual & 186.374 & 265 & 0.703 & & \\
\hline & Total & 425.968 & 267 & & & \\
\hline \multirow{2}{*}{\multicolumn{2}{|c|}{ Model }} & \multicolumn{2}{|c|}{ Unstandardized Coefficients } & Standardized Coefficients & \multirow[t]{2}{*}{$\mathrm{t}$} & \multirow[t]{2}{*}{ Sig. } \\
\hline & & $\mathrm{B}$ & Std. Error & Beta & & \\
\hline \multirow[t]{3}{*}{1} & (Constant) & .464 & .383 & & 1.213 & .226 \\
\hline & P_INVEST & .455 & .057 & .374 & 8.051 & .000 \\
\hline & K_INVEST & .494 & .047 & .493 & 10.606 & .000 \\
\hline \multicolumn{2}{|c|}{ Model } & 1 & Change Statistics & R Square Change & \multicolumn{2}{|l|}{0.562} \\
\hline \multicolumn{2}{|l|}{$\mathrm{R}$} & $.750^{\mathrm{a}}$ & & F Change & \multicolumn{2}{|l|}{170.337} \\
\hline \multicolumn{2}{|c|}{ R Square } & 0.562 & & df1 & \multicolumn{2}{|l|}{2} \\
\hline \multicolumn{2}{|c|}{ Adjusted R Square } & 0.559 & & df2 & \multicolumn{2}{|l|}{265} \\
\hline \multirow{2}{*}{\multicolumn{2}{|c|}{ Std. Error of the Estimate }} & 0.839 & & Sig. F Change & \multicolumn{2}{|l|}{0} \\
\hline & & & Durbin-Watson & & 1.985 & \\
\hline \multicolumn{7}{|c|}{ a. Dependent Variable: J_INVEST } \\
\hline \multicolumn{7}{|c|}{ b. Predictors: (Constant), K_INVEST, P_INVEST } \\
\hline
\end{tabular}

The R-square value of the direct influence of this study was 0.562 indicating that the strength of investment knowledge and investment habits was able to explain and influence the investment champion variable in the pandemic COVID 19 period in Samarinda society by 56.20 percent from the total sample of 268 respondents in 2020. This means that the investment knowledge and investment habits variables can explain the investment champion variable in the pandemic COVID 19 period in samarinda society by 56.20 percent while the remaining 43.80 percent is influenced by other variables outside of this study.

T test on the variable of investment knowledge and investment habits is partially significant 0,000 $<0.005$ with $\mathrm{T}$ values of 8.051 and 10.606 , this means that there is a partially significant influence of investment knowledge and investment habits that is significant and positive towards the Investment Champion. And based on the table, formula formulas from the unstandardized coefficients can be formed, namely:

$$
J_{-} \text {Invest }_{t}=0,464+0,454 P_{-} \text {Invest }_{t}+0,494 K_{-} \text {Invest }_{t}
$$

Interpretation of the regression, namely: Constant (a) means that if all free variables have a value of zero (0) then the value of the dependent variable (Beta Investment Champion) is 0.464 , the value of the Investment Knowledge coefficient for variable X1 and Investment Habits respectively 0.454 and 0494 This implies that partially each increase in Investment Knowledge and Investment Habits of one unit then the Beta (Y) variable will increase respectively X1 and X2 respectively 0.454 and 0494 assuming that the other independent variables from the regression model are fixed.

\section{RESUME}

Extensive and complex investment knowledge about the market, the behavior of market participants and the investment system in the generally accepted trading mechanism leads to investment habits, new refraction in investing becomes investment control in the face of changing life that occurred during the copandemic period19. Knowledge that changes behavior by applying champion investment habits produces dramatically better returns, using a computerized trading system, applying investment habits that always want to keep money safely as an emergency fund, so investment returns will surge. Investment beliefs drive your investment behavior, mental strategies of investment philosophy drive internal awareness and the unconscious process of investment champions by maintaining emotions, great curiosity and enthusiasm and investment expertise that is connected with good people who are valued, trusted, and admired.

\section{ACKNOWLEGDEMENT}

Special Thank you to the KKN-KLB Batch 46 program of Mulawarman University which was initiated by LP2M Unmul with the Chancellor's Decree No: 994 / SK / 2020 dated June 23, 2020, which contributed to the success of budgeting for Field Assistance Lecturer service activities who have successfully compiled the final report during the activity.

\section{REFERENCES}

1. He, H., \& Harris, L. (2020). The Impact of Covid19 Pandemic on Corporate Social Responsibility 
and Marketing Philosophy. Journal of Business Research.

2. Sheth, J. (2020). Impact of Covid-19 on Consumer Behavior: Will the Old Habits Return or Die?. Journal of Business Research.

3. Yoshino, N., Taghizadeh-Hesary, F., \& Otsuka, M. (2020). Covid-19 and Optimal Portfolio Selection for Investment in Sustainable Development Goals. Finance Research Letters, 101695.

4. Villanueva, D., González-Carrasco, I., LópezCuadrado, J. L., \& Lado, N. (2016). SMORE: Towards a semantic modeling for knowledge representation on social media. Science of Computer Programming, 121, 16-33.

5. Neuman, Y., Hames, H., \& Cohen, Y. (2017). An information-based procedure for measuring semantic change in historical data. Measurement, 105, 130-135.

6. Lupiani-Ruiz, E., GarcíA-Manotas, I., ValenciaGarcíA, R., GarcíA-SáNchez, F., CastellanosNieves, D., FernáNdez-Breis, J. T., \& CamóNHerrero, J. B. (2011). Financial news semantic search engine. Expert systems with applications, 38(12), 15565-15572.

7. Fedushko, S., \& Benova, E. (2019). Semantic analysis for information and communication threats detection of online service users. Procedia Computer Science, 160, 254-259.

8. Boholm, M. (2017). The semantic field of risk. Safety science, 92, 205-216.

9. Liu, D., Ji, Y., \& Mookerjee, V. (2011). Knowledge sharing and investment decisions in information security. Decision Support Systems, 52(1), 95-107.

10. Forbes, J., \& Kara, S. M. (2010). Confidence mediates how investment knowledge influences investing self-efficacy. Journal of economic psychology, 31(3), 435-443.

11. Irani, Z., Sharif, A., Kamal, M. M., \& Love, P. E. (2014). Visualising a knowledge mapping of information systems investment evaluation. Expert Systems with Applications, 41(1), 105-125.

12. Jiao, H., Zhou, J., Gao, T., \& Liu, X. (2016). The more interactions the better? The moderating effect of the interaction between local producers and users of knowledge on the relationship between $\mathrm{R} \& \mathrm{D}$ investment and regional innovation systems. Technological Forecasting and Social Change, 110, 13-20.

13. Liu, D., Ji, Y., \& Mookerjee, V. (2011). Knowledge sharing and investment decisions in information security. Decision Support Systems, 52(1), 95-107.

14. Malik, A., Froese, F. J., \& Sharma, P. (2020). Role of HRM in knowledge integration: Towards a conceptual framework. Journal of Business Research, 109, 524-535.

15. Powell, K. S., \& Lim, E. (2017). Investment motive as a moderator of cultural-distance and relative knowledge relationships with foreign subsidiary ownership structure. Journal of Business Research, 70, 255-262.

16. Wilinski, A., \& Kovalerchuk, B. (2017). Visual knowledge discovery and machine learning for investment strategy. Cognitive Systems Research, 44, 100-114.

17. Hooker, R. H. (2017). The Determinants and Implications of Millennials' Stock Market Investment Habits and Opinions (Doctoral dissertation, Appalachian State University).

18. Alhassan, A., \& Naka, A. (2020). Corporate future investments and stock liquidity: Evidence from emerging markets. International Review of Economics \& Finance, 65, 69-83.

19. Chortareas, G., Noikokyris, E., \& Rakeeb, F. R. (2020). Investment, firm-specific uncertainty, and market power in South Africa. Economic Modelling.

20. Christensen, J. L., \& Hain, D. S. (2017). Knowing where to go: The knowledge foundation for investments in renewable energy. Energy Research \& Social Science, 25, 124-133.

21. Frickel, S., Campanella, R., \& Vincent, M. B. (2009). Mapping knowledge investments in the aftermath of Hurricane Katrina: a new approach for assessing regulatory agency responses to environmental disaster. Environmental Science \& Policy, 12(2), 119-133.

22. Hibbert, A. M., Kang, Q., Kumar, A., \& Mishra, S. (2020). Heterogeneous beliefs and return volatility around seasoned equity offerings. Journal of Financial Economics.

23. Hoffmann, A. O., \& Post, T. (2016). How does investor confidence lead to trading? Linking investor return experiences, confidence, and investment beliefs. Journal of Behavioral and Experimental Finance, 12, 65-78.

24. Shahid, M. S., \& Abbas, M. (2019). Does corporate governance play any role in investor confidence, corporate investment decisions relationship? Evidence from Pakistan and India. Journal of Economics and Business, 105, 105839.

25. Chong, A., \& Srebot, C. (2020). Investment confidence and regional trade agreements with the United States. International Economics.

26. Samdani, T. (2019). Anchor-backed IPOs, reported earnings, and heterogeneous investors' beliefs. Journal of Corporate Finance, 59, 72-87.

27. Brunekreeft, G. (2004). Market-based investment in electricity transmission networks: controllable flow. Utilities Policy, 12(4), 269-281.

28. Platanakis, E., Sakkas, A., \& Sutcliffe, C. (2019). Harmful diversification: Evidence from alternative investments. The British Accounting Review, 51(1), $1-23$.

29. Ljubownikow, G., \& Ang, S. H. (2020). Competition, diversification and performance. Journal of Business Research, 112, 81-94. 
30. Iglesias-Casal, A., López-Penabad, M. C., LópezAndión, C., \& Maside-Sanfiz, J. M. (2020). Diversification and optimal hedges for socially responsible investment in Brazil. Economic Modelling, 85, 106-118.

31. Vishwavidyalaya, D. A., \& Welfare, S. (2018). "A Study of Investment habits of Professional Women in Indore city Laxmikant Tripathi," 10(1), 20-26

32. Kakkattuchali, A. S. (2019). "A Study on the Investment Behaviour of Gulf Migrants with Special Reference to Malappuram District," New Front. Business, Manag. Technol. OPEN, 09(01), 238-246.

33. Flori, A. (2019). News and subjective beliefs: A Bayesian approach to Bitcoin investments. Research in International Business and Finance, 50, 336-356.

34. Cooper, D. J., \& Kagel, J. H. (2001). "Locus of Control and Investment in Risky Assets," J. Econ. Behav. Organ, 13, 63-76

35. Ngadino. (2019). "The Influence of Investment Knowledge, Perceived Risk and Perceived Behavioral Control towards Stock Investment Intention," www.ijbmm.com Int. J. Bus. Mark. Manag, 4(1), 2456-4559.

36. Chalmers, J., \& Reuter, J. (2020). Is conflicted investment advice better than no advice?. Journal of Financial Economics.

37. Bruce, B., \& Greene, J. (2014). Investment Philosophy and Process.

38. Yu, X., Wu, Z., Wang, Q., Sang, X., \& Zhou, D. (2020). Exploring the investment strategy of power enterprises under the nationwide carbon emissions trading mechanism: A scenario-based system dynamics approach. Energy Policy, 140, 111409.

39. Keränen, J., \& Liozu, S. (2020). Value champions in business markets: Four role configurations. Industrial Marketing Management, 85, 84-96.

40. Lahmiri, S., \& Bekiros, S. (2020). Renyi entropy and mutual information measurement of market expectations and investor fear during the COVID19 pandemic. Chaos, Solitons \& Fractals, 139, 110084.

41. Dimov, B. C., Atanasoska, T., Iliev, D., Andonovska-Trajkovska, D., \& SewerynKuzmanovska, M. (2015). Importance of investment in research's of students and teachers epistemological and pedagogical beliefs. ProcediaSocial and Behavioral Sciences, 191, 1299-1303.

42. Basuchoudhary, A., \& Searle, N. (2019). Snatched secrets: Cybercrime and trade secrets modelling a firm's decision to report a theft of trade secrets. Computers \& Security, 87, 101591.

43. Qian, M., Sun, P. W., \& Yu, B. (2018). Top managerial power and stock price efficiency: Evidence from China. Pacific-Basin Finance Journal, 47, 20-38.

44. Sakawa, H., \& Watanabel, N. (2018). Board structures and performance in the banking industry: Evidence from Japan. International Review of Economics \& Finance, 56, 308-320.

45. Juravle, C., \& Lewis, A. (2009). The role of championship in the mainstreaming of sustainable investment (SI) what can we learn from SI pioneers in the United Kingdom?. Organization \& Environment, 22(1), 75-98. 